\title{
INTERNATIONAL FINANCIAL REPORTING STANDARDS ADOPTION, INVESTOR PROTECTION, AND FOREIGN PORTFOLIO INVESTMENT: A REVIEW
}

\author{
Md. Kamrul Hasan Shovon \\ Assistant Professor \\ Department of Accounting and Information Systems \\ University of Rajshahi, Bangladesh \\ E-mail: kamrul@ru.ac.bd
}

Received: October 10, $2021 \quad$ Accepted: October 30, $2021 \quad$ Online Published: November 21, 2021

DOI: 10.46281/ijafr.v9i1.1449

URL: https://doi.org/10.46281/ijafr.v9i1.1449

\begin{abstract}
This paper aims to analyze the impacts of International Financial Reporting Standards (IFRS) adoption on foreign portfolio investment (FPI) in relation to investor protection based on existing empirical literature. This study uses a historical approach and focuses on thirty-six relevant articles published in accounting and finance journals. The author provides a theoretical groundwork of the association between IFRS adoption and FPI and summarizes the results. The findings are critically analyzed by employing developed vs. developing country lens. The review study reveals that the effects of IFRS adoption on FPI significantly differ between developed and developing countries. Although the positive impact of IFRS adoption on FPI is documented in existing literature, not all countries (particularly developing countries), firms, and users have benefited or equally benefited from IFRS adoption regarding FPI. In addition, the positive impacts of IFRS adoption on FPI are associated with the country's regulatory environment, such as level of investor protection. The findings of the study suggest that developing countries should ensure a proper regulatory environment to reap the full benefits of IFRS adoption. This review contributes to the existing literature by providing a comparative analysis of IFRS adoption effect on FPI between developed and developing countries while also suggests future research avenues.
\end{abstract}

Keywords: IFRS Adoption, International Accounting Standards (IAS), FPI, Foreign Shareholdings, Investor Protection.

JEL Classification Codes: M41, Z23, B17.

\section{INTRODUCTION}

With the emergence of globalization, corporate giants worldwide are expanding their business in every corner of the world. However, the use of different accounting systems and the prevalence of local accounting standards hinder uniform financial reporting throughout the world (International Accounting Standard Board [IASB], 2002). Thus, professional accountants worldwide assume that uniform accounting standards will harmonize the accounting practices worldwide and, in turn, will bring the financial reporting practices under one umbrella. IFRS is a single set of uniform accounting or financial 
reporting standards globally recognized for financial statement preparation (Association of International Certified Professional Accountants [AICPA], 2021).

Proponents of IFRS have consistently claimed that adopting IFRS helps reduce information asymmetry, improve comparability, transparency, and quality of financial information, and thereby, lead to greater flows of cross-border investment, particularly FPI (Levitt, 1998; IASB, 2002; White, 2008). Although overall positive impact of IFRS adoption on FPI is documented in existing literature (Amiram, 2012; Hamberg, Mavruk, \& Sjögren, 2013; Yu \& Wahid, 2014; DeFond, Hu, Hung, \& Li, 2011; Florou \& Pope, 2012; Beneish, Miller, \& Yohn, 2015; Hansen, Miletkov, \& Wintoki, 2015), not all countries particularly developing countries such as China (DeFond, Gao, Li, \& Xia., 2014), South Africa (Sherman \&, Klerk, 2015), Nigeria (Udofia, 2018), and Malaysia (Shovon, 2019) have benefited or equally benefited from these changes. This evidence indicates that there are inconsistent findings regarding the impacts of IFRS adoption on FPI between developed and developing countries. In explaining the inconsistent relationship between IFRS adoption and FPI, this study aims to review and summarize the existing researches on the impacts of IFRS on FPI from the developed and developing country perspective and provide suggestions for future research. In addition, this research presents a clear understanding of the association between IFRS adoption on FPI and explains these inconsistencies in relation to countries institutional settings or regulatory environment.

A number of researchers conducted review on IFRS adoption literature highlighting different aspects of IFRS adoption such as impacts of IFRS adoption on accounting quality (for example, Păşcan, 2015; Soderstrom, \& Sun, 2007), auditing (for example, Khlif \& Achek, 2016), comparability, foreign trade, and investment, earnings management, market liquidity, cost of equity, cost of debt and firm performance (Ahmed, Chalmers, \& Khlif, 2013; Brüggemann et al., 2013; De George \& Shivakumar, 2016; Houqe, 2018; Mohammadrezaei, Mohd-Saleh, \& Banimahd, 2015; Samaha \& Khlif, 2016; Singleton-Green, 2015). However, limited review studies mainly concentrate on the impacts of IFRS adoption on FPI concerning investor protection. In addition, the most recent reviews on IFRS adoption literature were conducted in 2018 , and this study aims to advance the literature by considering recently published articles until October 2021.

Most of the reviewed studies reveal that IFRS adoption has a positive impact on FPI. However, some significant caveats are worth noting. Firstly, prior studies indicate that the increase in FPI at the post IFRS adoption periods are restricted to countries and firms that had strong enforcement, regulatory environment, reporting incentives, implementation credibility, and higher governance quality (Amiram, 2012; Yu \& Wahid, 2014; Florou \& Pope, 2012; Hansen et al., 2015). Secondly, existing review studies suggest that most of the research on IFRS adoption is conducted in developed country context (Lin, 2012; Singleton-Green, 2015), and there is a limited study that investigate the impacts of IFRS adoption in developing countries (Lin, 2012; Herbert \& Tsegba, 2013; Efobi Uchenna, 2016; Mohammadrezaei et al., 2015; Samaha \& Khlif, 2016). This indicates that the outcome may not directly apply or is less likely to generalize to developing countries (Lin, 2012; Mohammadrezaei et al., 2015). Further, it is argued that there is a significant difference in institutional features such as regulatory and enforcement environment between developed and developing countries (Mohammadrezaei et al., 2015). Therefore, it is necessary to investigate the impacts of IFRS on FPI, focusing on developed vs. developing country perspectives.

This study adopts a historical approach and focuses on the articles published in finance and accounting journal. The following keywords, such as IFRS adoption, foreign portfolio investment, foreign shareholdings, and investor protection, are selected to categorize relevant studies for this literature review. Searching these key terms in the databases, such as Taylor and Francis, Elsevier, Springer, JSTOR, American Accounting Association, Wiley, Emerald, Social Science Research Network (SSRN), and Google Scholar, a total number of thirty-six empirical studies dealing with IFRS adoption, FPI and investor protection are found. This literature review reveals that the effects of IFRS adoption on FPI significantly differ between developed and developing countries. This initial evidence in IFRS adoption on FPI literature implies that this issue is still in its infancy, and further research is required to capture the effect of IFRS adoption on FPI in developing country settings. 
Conducting a review of the IFRS adoption effects on FPI is of critical importance for researchers and regulators. For researchers, this paper complements these reviews that focus on IFRS adoption effects on FPI by shedding light on developed and developing countries. Our study suggests that the impact of IFRS adoption on FPI is fertile ground for future empirical investigations. Authors should refine their analysis at a single developing country to capture the actual effect of IFRS adoption on FPI. Our review is of timely importance for regulators, given the renewed debate about IFRS adoption impacts between developed and developing countries.

\section{UNDERSTANDING ASSOCIATION BETWEEN IFRS ADOPTION AND FPI}

Mean-Variance Portfolio Theory (MVPT) suggests that good diversification can optimize the return and, at the same time, reduce the risk in portfolios (Markowitz, 1952, 1959). By diversifying portfolios, investors can take the opportunity to maximize their return and diversify risk (Ackert, Church, Tompkins, \& Zhang, 2005). Therefore, MVPT recommends a globally diversified portfolio of equities for investors (Caprio, 2012) to diversify their risk internationally (Markowitz, 1952). Sharpe (1964) subsequently adopted the MVPT and introduced Capital Asset Pricing Model (CAPM), which asserts that investors representing a country ought to hold a world market portfolio (Coeurdacier \& Rey, 2013). In other words, foreign investors should possess each country's assets that are equivalent to the country's share in the global market portfolio (De Santis, 2010). Based on CAPM, Levy and Sarnat (1970) and Solnik (1974) demonstrated the benefits of international diversification. Simulations of Lewis (1999 p. 578) forecast that American portfolios should acquire a minimum of $40 \%$ of foreign assets. Nonetheless, the actual proportion of American-owned foreign assets ranges from approximately $8 \%$ only (Lewis, 1999 p. 578). This phenomenon indicates that the ratio of foreign investment is pointedly lower than what is deemed optimal under CAPM (French \& Poterba, 1991; Cooper \& Kaplanis, 1994). Investors appear cautious about reaping the maximum benefits of international diversification and acquiring an unbalanced share of local equities (Coeurdacier \& Rey, 2013).

The internationally diversified portfolio can reduce portfolio risk (Solnik, 1995; Butler, 2016). It is argued that portfolio risk can be minimized by diversifying the portfolio in foreign as well as local assets (Abid, Leung, Mroua, \& Wong, 2014). Based on the idea of diversification, prior literature suggests that investors can reduce the investment risk by investing in the stock market of different countries or incorporating foreign assets in their portfolios (Grubel, 1968; Levy \& Sarnat, 1970). More recently, Solnik (1995) and Asness, Israelov and Liew (2011) measured the risk-reduction benefits of international portfolio diversification. By adding more stocks to a U.S. portfolio, Solnik (1995) documents that the gain from international diversification is substantial. Similarly, by observing the return of the domestic portfolio, Nieuwerburgh and Veldkamp (2009) report substantial gain from international diversification. However, despite the potential benefit of diversification, the strong bias in favor of local assets is a well-recognized characteristic of global portfolios investment (Coval \& Moskowitz, 1999).

International diversification of assets would be beneficial to investors because there are gains to be had from diversification (Gokkent, 1997). It is extensively recognized that investors should hold a well-diversified portfolio unless there are reasons (such as information barriers) to deviate from this norm (Cooper, Sercu, \& Vanpée, 2013). However, previous studies have consistently found that globally, investors significantly undermine foreign investments or are disinclined to hold securities outside their local markets (French \& Poterba, 1991; Lewis, 1995; Ahearne, Griever, \& Warnock, 2004). For example, French and Poterba (1991) and Lewis (1995) reveal that investors are reluctant to diversify the portfolio and hold more domestic firms' shares. Tesar and Werner (1995) assert that investment decisions of Canadian and U.S. investors do not reflect pure diversification motive. These findings suggest that investors forgo the possible benefit of diversification, which is puzzling and contradicts CAPM predictions (Gehrig, 1993; Karolyi \& Stulz, 2003). This under-diversification phenomenon is referred to as home bias.

Home bias refers to the tendency of domestic investors to invest more in domestic equities or hold a small portion of their wealth in foreign equities compared to the predictions of CAPM (Faruqee, 
Li, \& Yan, 2004; Yan, 2004). It is argued that the worldwide adoption of IFRS can reduce this information barrier, thereby reducing home bias and enhancing cross-border investment flows (Levitt, 1998; IASB, 2002; White, 2008). Therefore, based on the predictions of MVPT and CAPM, it is expected that adopting IFRS contributes to reducing investors' home bias and thereby increasing the FPI of a country. However, there is little evidence regarding how global integration of financial reporting, such as IFRS adoption can mitigate home bias (Amiram, 2012) and thereby increase FPI, particularly in developing countries.

\section{IFRS ADOPTION AND FPI}

A considerable amount of literature (refer to Table 1) has been published on the effect of IFRS adoption on FPI. Most of these prior research works demonstrate that IFRS adoption enhances firms' as well as countries' ability to attract greater FPI. These benefits are due to improved familiarity (Amiram, 2012; Hamberg et al., 2013; Yu \& Wahid, 2014) and reducing information asymmetry (explained by comparability, reporting quality, and transparency) after IFRS adoption (Beneish et al., 2015; DeFond et al., 2011; Florou \& Pope, 2012; Hansen et al., 2015).

Familiarity is one of the critical issues that prior studies consider explaining the relationship between IFRS adoption and FPI. A number of literary works (Bradshaw, Bushee, \& Miller, 2004; Covring, Defond, \& Hung, 2007; Amiram, 2012; Hamberg et al., 2013; Yu \& Wahid, 2014; Garrouch 2016) find that familiarity of investors on accounting standards assists investment decisions and thereby, encourages FPI. Their findings are rational with the claims that the IFRS adoption facilitates investors in evaluating the performance of foreign firms and the market by establishing uniform accounting or reporting standards (Amiram, 2012). For example, studying firm-level holding of more than 25,000 mutual funds, Covring et al. (2007) suggest that average holdings of the foreign mutual funds are significantly higher for a firm that adopts International Accounting Standards (IAS). Authors further indicate that investors' information processing costs are reduced after IAS adoption, providing information in a more familiar form.

In addition, Bradshaw et al. (2004) reveal that companies using accounting or financial reporting standards similar to US GAAP receive a high level of U.S. institutional investors. This is because such accounting practices are more familiar to U.S. investors. Additionally, Amiram (2012) and Yu and Wahid (2014) mention that countries and firms that adopt IFRS experience a greater level of FPI. Their findings indicate that familiarity with IFRS drives the increase in foreign shareholdings. Apart from this, Hamberg et al. (2013) find that FPI increased in Swedish firms following IFRS adoption, mainly from other IFRS adopting countries. Authors argue that the increase in FPI is driven by the investor's familiarity with reporting standards. Similarly, Omotoso, Schutte, and Oberholzer (2021) suggest that the adoption of IFRS increases FPI in African countries. These outcomes imply that adopting IFRS in a country enables domestic investors to familiarize themselves with accounting standards of more countries, help reduce investors' information processing costs, and eventually increase FPI.

Information asymmetry is considered another critical factor in explaining the relationship between IFRS adoption and FPI. Prior studies demonstrate information asymmetry in terms of comparability, reporting quality, and transparency (DeFond et al., 2011; Beneish et al., 2015; Hansen et al., 2015). Contemporaneous studies (Yu, 2010; DeFond et al., 2011; Khurana \& Michas, 2011; Florou \& Pope, 2012) assert that mandatory adoption of IFRS enhances comparability of financial information and thus promotes greater FPI (see Table 1 for details). Their outcomes are consistent with the arguments that harmonization around IFRS improves reporting quality and comparability and, thus, reduces information asymmetry (Levitt, 1998; IASB, 2002). Similarly, Lee and Fargher (2010) suggest a uniform accounting standard is likely to enhance the comparability of financial information across companies and thereby assist in reducing information asymmetry.

Besides that, DeFond, Hu, Hung, and Li (2012) assert that the relative attraction of U.S. firms to foreign investors reduced after worldwide IFRS adoption. Their findings are consistent with the claim that a single set of financial reporting standards enables global investors to minimize information processing costs. As a result, firms can enjoy relatively greater comparability benefits through IFRS 
adoption. Empirical evidence of Hong, Hung and Lobo (2014) imply that adoption of IFRS reduces information asymmetry between a business entity and its stakeholders and enables firms to increase earnings from overseas markets. Hsu and Lai (2013) suggest that firms using IFRS-based standards experience greater foreign mutual fund ownership than firms with local reporting standards. Additionally, Manyara (2017), Chen, Ng, and Tsang (2015), as well as Wang, Welker, and Wu (2015) examine how the adoption of IFRS influences firms' decisions regarding listing in foreign stock markets. Their findings recommend that the implementation of IFRS encourages the volume of cross-listings and improves access to equity capital. Apart from this, Han, Yi, Park, and Seo (2016) examine whether the adoption of IFRS enhances the effectiveness of financial information in Korea. Their result suggests that foreign investments in small firms have significantly improved after IFRS adoption.

Empirical research suggests that the quality of financial information increased following IFRS adoption (Leuz, 2003; Bartov, Goldberg, \& Kim, 2005; Barth, Landsman, \& Lang, 2008; Armstrong, Barth, Jagolinzer, \& Riedl, 2010). This increased reporting quality helps to lessen information asymmetries (Ashbaugh \& Pincus, 2001; Tarca, 2004; Beneish \& Yohn, 2008) and thereby facilitate foreign investors to make global investment decisions (Hsu \& Lai, 2013; Beneish et al., 2015). In addition, existing literature (Shima \& Gordon, 2011; Florou \& Pope, 2012; Beneish et al., 2015; Hsu, Jung, \& Pourjalali, 2015) reveals that increased FPI following the adoption of IFRS is more likely an outcome of improved reporting quality (see Table 1 for details).

Besides that, Rueda-Sabater (2000), Chipalkatti, Le, and Rishi (2007) and Akisik and Pfeiffer (2009) assert that in a developing or emerging economy, foreign equity ownership is positively linked with the level of corporate governance and quality of reporting standards. Similarly, Bradshaw et al. (2004) suggest that U.S. institutional investors invest more in companies that follow reporting standards consistent with US GAAP. This is because such accounting practices are perceived as higher quality. Additionally, Bova and Pereira (2012) assert that cross-border investment is positively allied with IFRS compliance. Their findings are consistent with the claim that international investors demand a highquality financial or accounting standard to protect their investments within the companies. Apart from these, Ahearne et al. (2004) state that disclosure requirements, financial reporting standards, and regulatory environment are important factors for explaining the home bias. This is because higher disclosures rules limit the chance of domestic investors having access to private information.

Transparency is an essential issue in explaining information asymmetry as well as the relationship between IFRS and FPI. Prior empirical studies (Aggarwal, Klapper, \& Wysocki, 2005; Brüggemann, 2011; Hansen, Miletkov, \& Wintoki, 2013; Hansen et al., 2015; Garrouch, 2016) claim that the transparency effect of IFRS is positively associated with FPI. Their outcomes are consistent with the claims that transparency decreases information asymmetries, strengthens the comparability effect (Nnadi \& Soobaroyen, 2015), and promotes foreign investment (Babío \& Muiño, 2005; MárquezRamos, 2011). For example, Hansen et al. (2015) argue that firms can increase the transparency of financial information through IFRS adoption and attract more foreign investment. Similarly, Garrouch (2016) reveals that international accounting harmonization enhances foreign shareholdings of PLCs in France. The result implies that assuming transparency benefits foreign investors seeking to invest in companies that apply international accounting or reporting standards.

Besides that, Aggarwal et al. (2005) suggest that emerging markets with high-quality financial reporting standards attract greater U.S. mutual fund investment. The result is more pronounced for companies that ensure greater transparency in accounting information. Additionally, Hansen et al. (2013) suggest that firms using IFRS with strong reporting incentives and more transparent financial disclosures have experienced greater foreign shareholdings. Besides this, Brüggemann (2011) investigates the consequences of IFRS adoption on international capital flows concerning transparency. The author finds that the adoption of IFRS significantly increases the open market trading activity of stocks.

Despite the documented positive impacts of IFRS adoption, it is also evidenced that adoption of IFRS does not have a substantial positive effect on FPI in several countries, particularly in developing countries. For example, with a sample of 5518 firm-year observations from China for 2005-2008, 
DeFond et al. (2014) suggest that IFRS adoption has no substantial effect on foreign shareholdings in China. Similarly, using a sample of 40 South African firms for 2001-2006, Sherman and De Klerk (2015) reveal no substantial increase in foreign shareholdings following IFRS adoption in South Africa. Additionally, Udofia (2018) examines the impacts of IFRS adoption on FPI in Nigeria and suggests that compared to the post- IFRS adoption period, the pre- IFRS adoption period has a greater frequency of growth in FPI. Further, with a sample of 5784 firm-year observations from Malaysia for the period 20082011 and 2013-2016, Shovon (2019) reveal that adopting IFRS had no significant positive effect on FPI in Malaysia. Besides that, some cross-country studies suggest that the adoption of IFRS has no significant impact on foreign shareholdings in countries where investors' rights are not well protected (Shima \& Gordon, 2011; Hansen et al., 2015). Since developing countries frequently suffer from weak investor protection, this finding indicates that the positive effects of IFRS adoption on foreign shareholdings are not substantial in developing countries. Overall, these findings suggest that IFRS adoption's impact on FPI significantly differs between developed and developing countries.

Table 1. Summary of studies on the association between IFRS adoption and FPI

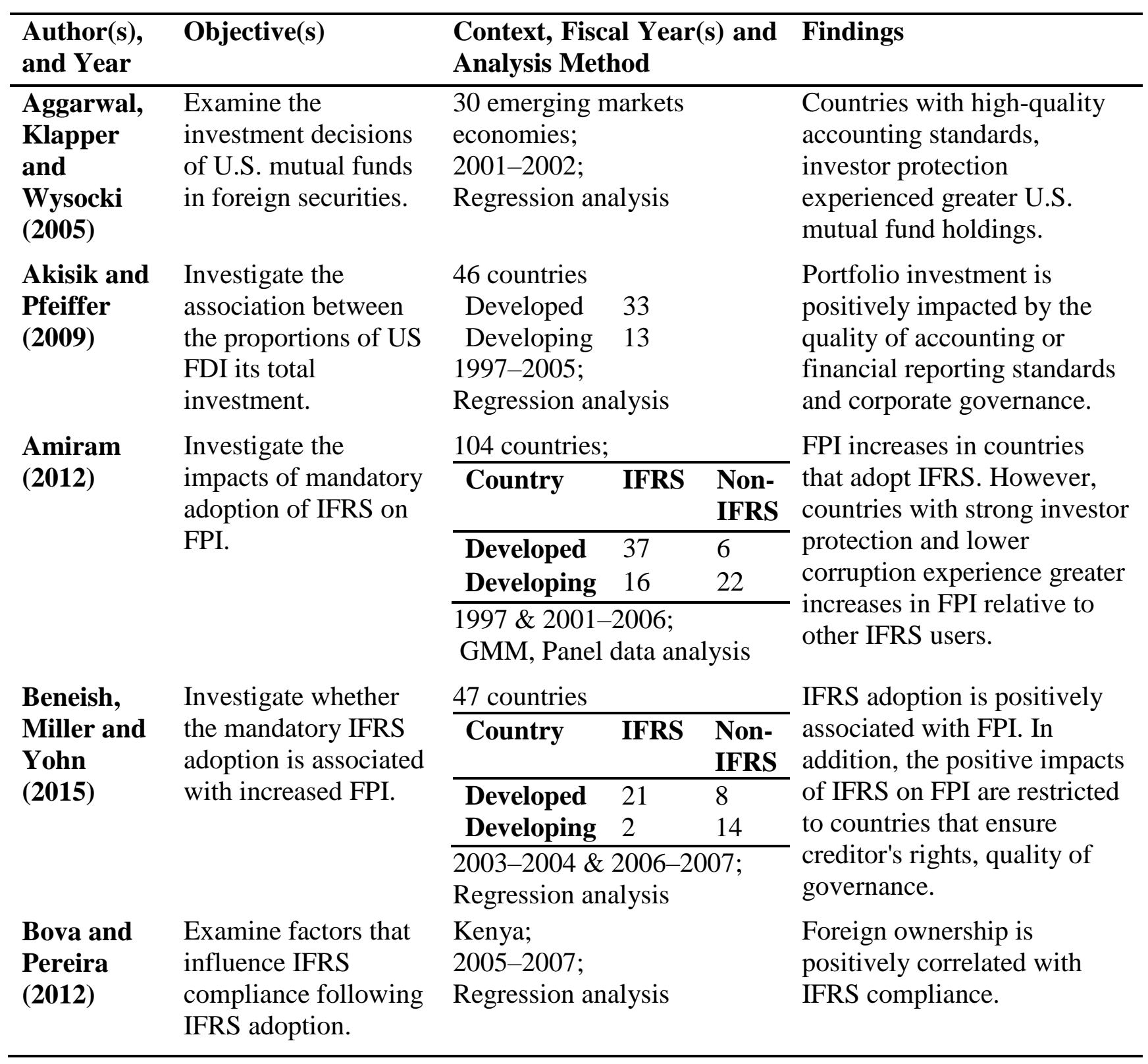




\begin{tabular}{|c|c|c|c|c|}
\hline $\begin{array}{l}\text { Author(s), } \\
\text { and Year }\end{array}$ & Objective(s) & \multicolumn{2}{|c|}{$\begin{array}{l}\text { Context, Fiscal Year(s) and } \\
\text { Analysis Method }\end{array}$} & Findings \\
\hline $\begin{array}{l}\text { Bradshaw, } \\
\text { Bushee and } \\
\text { Miller } \\
(\mathbf{2 0 0 4 )}\end{array}$ & $\begin{array}{l}\text { Examine the } \\
\text { association between } \\
\text { accounting practice } \\
\text { and assets allocation } \\
\text { choice of U.S. } \\
\text { institutional investors } \\
\text { in foreign firms. }\end{array}$ & \multicolumn{2}{|l|}{$\begin{array}{l}89078 \text { firm-year } \\
\text { observations from } 50 \\
\text { countries; } \\
\text { 1989-1999; } \\
\text { Panel data regression } \\
\text { analysis }\end{array}$} & $\begin{array}{l}\text { Firms that use accounting or } \\
\text { financial reporting standards } \\
\text { equivalent to the US GAAP } \\
\text { attract greater U.S. } \\
\text { institutional investment. }\end{array}$ \\
\hline \multirow{5}{*}{$\begin{array}{l}\text { Brüggema } \\
\text { nn (2011) }\end{array}$} & \multirow{5}{*}{$\begin{array}{l}\text { Examine whether the } \\
\text { mandatory IFRS } \\
\text { adoption impacts } \\
\text { open markets trading } \\
\text { activities. }\end{array}$} & \multicolumn{2}{|c|}{4869 firms from 34 countries } & \multirow{5}{*}{$\begin{array}{l}\text { Firms experienced substantial } \\
\text { growth in open market } \\
\text { trading activities following } \\
\text { IFRS adoption. }\end{array}$} \\
\hline & & Country IFRS & $\begin{array}{l}\text { Non- } \\
\text { IFRS }\end{array}$ & \\
\hline & & Developed & 7 & \\
\hline & & Developing & 5 & \\
\hline & & $\begin{array}{l}2001-2007 ; \\
\text { Regression analysis }\end{array}$ & & \\
\hline \multirow{5}{*}{$\begin{array}{l}\text { Chen, Ng } \\
\text { and Tsang } \\
(2015)\end{array}$} & \multirow{5}{*}{$\begin{array}{l}\text { Examine whether the } \\
\text { mandatory adoption } \\
\text { of IFRS impacts the } \\
\text { company's cross- } \\
\text { listing activities. }\end{array}$} & \multicolumn{2}{|c|}{1181 firms from 34 countries } & \multirow{5}{*}{$\begin{array}{l}\text { The firm's cross-listing } \\
\text { activities are positively } \\
\text { affected by the mandatory } \\
\text { IFRS adoption. These } \\
\text { changes are allied with the } \\
\text { level of differences between } \\
\text { local accounting standards } \\
\text { and IFRS. }\end{array}$} \\
\hline & & $\begin{array}{ll}\text { Country } & \text { IFRS }\end{array}$ & $\begin{array}{l}\text { Non- } \\
\text { IFRS }\end{array}$ & \\
\hline & & Developed 15 & 6 & \\
\hline & & & 11 & \\
\hline & & $\begin{array}{l}2003-2004 \text { \& 2006-2 } \\
\text { Panel data regression }\end{array}$ & & \\
\hline \multirow{5}{*}{$\begin{array}{l}\text { Covring, } \\
\text { Defond and } \\
\text { Hung } \\
(\mathbf{2 0 0 7 )}\end{array}$} & \multirow{5}{*}{$\begin{array}{l}\text { Look at the impacts } \\
\text { of voluntary IAS } \\
\text { adoption on foreign } \\
\text { capital. }\end{array}$} & \multicolumn{2}{|c|}{$\begin{array}{l}25000 \text { mutual funds from } 29 \\
\text { countries }\end{array}$} & \multirow{5}{*}{$\begin{array}{l}\text { Companies using IAS } \\
\text { experienced greater foreign } \\
\text { mutual fund holdings } \\
\text { compared to companies that } \\
\text { use national reporting } \\
\text { standards. }\end{array}$} \\
\hline & & $\begin{array}{ll}\text { Country } & \text { IFRS }\end{array}$ & $\begin{array}{l}\text { Non- } \\
\text { IFRS } \\
\end{array}$ & \\
\hline & & Developed 19 & 3 & \\
\hline & & Developing 1 & 6 & \\
\hline & & \multicolumn{2}{|l|}{$\begin{array}{l}\text { 1999-2002; } \\
\text { Regression analysis }\end{array}$} & \\
\hline $\begin{array}{l}\text { DeFond et } \\
\text { al. (2014) }\end{array}$ & $\begin{array}{l}\text { Look at how IFRS } \\
\text { adoption affects } \\
\text { foreign institutional } \\
\text { investment. }\end{array}$ & \multicolumn{2}{|c|}{$\begin{array}{l}5518 \text { firm-year observations } \\
\text { from China (Developing } \\
\text { Country); } \\
\text { 2005-2008; } \\
\text { Panel data regression } \\
\text { analysis }\end{array}$} & $\begin{array}{l}\text { Foreign institutional } \\
\text { investment decreases after } \\
\text { China's IFRS adoption. }\end{array}$ \\
\hline $\begin{array}{l}\text { DeFond et } \\
\text { al. (2012) }\end{array}$ & $\begin{array}{l}\text { Investigate the effect } \\
\text { of IFRS adoption on } \\
\text { foreign portfolio } \\
\text { investment in U.S. } \\
\text { firms. }\end{array}$ & \multicolumn{2}{|c|}{$\begin{array}{l}13496 \text { firm-year } \\
\text { observations from } 3374 \text { US } \\
\text { firms; } \\
\text { 2003-2004 \& 2006-2007; } \\
\text { Panel data regressions }\end{array}$} & $\begin{array}{l}\text { The relative attractiveness of } \\
\text { U.S. companies decreased } \\
\text { following worldwide IFRS } \\
\text { adoption. }\end{array}$ \\
\hline
\end{tabular}




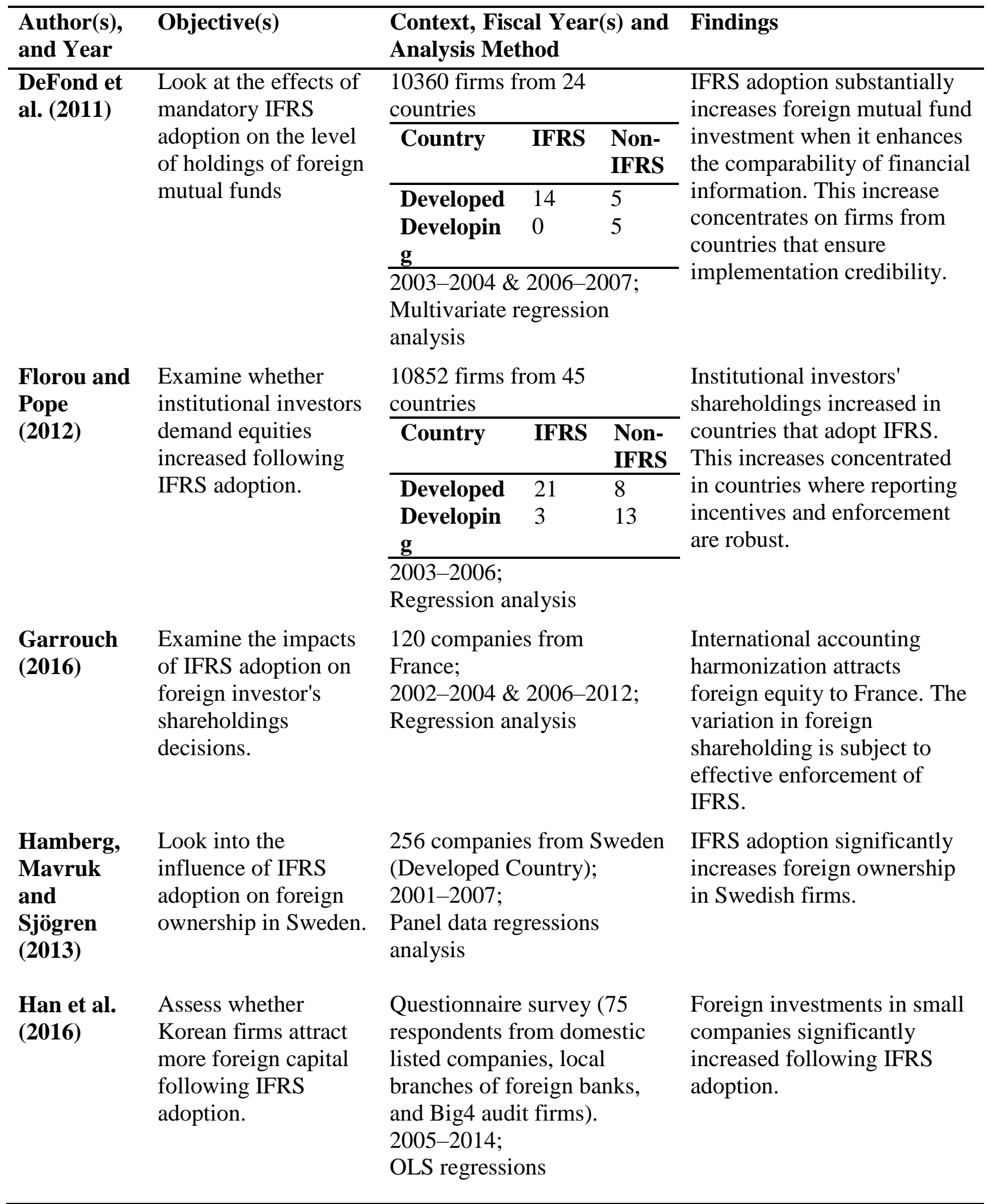




\begin{tabular}{|c|c|c|c|c|}
\hline $\begin{array}{l}\text { Author(s), } \\
\text { and Year }\end{array}$ & Objective(s) & $\begin{array}{l}\text { Context, Fiscal Year } \\
\text { Analysis Method }\end{array}$ & ) and & Findings \\
\hline \multirow{3}{*}{$\begin{array}{l}\text { Hansen, } \\
\text { Miletkov } \\
\text { and } \\
\text { Wintoki } \\
(2015)\end{array}$} & \multirow{3}{*}{$\begin{array}{l}\text { Examine whether } \\
\text { companies can attract } \\
\text { greater FPI through } \\
\text { enhancing the } \\
\text { transparency of } \\
\text { financial information. }\end{array}$} & $\begin{array}{l}55239 \text { firm-year } \\
\text { observations from } 51 \\
\text { countries }\end{array}$ & & \multirow{3}{*}{$\begin{array}{l}\text { Firms can enhance FPI by } \\
\text { advancing the transparency } \\
\text { of financial information. } \\
\text { However, there is no } \\
\text { relationship between FPI and } \\
\text { transparency following IFRS } \\
\text { adoption in countries with } \\
\text { weak investor protection. }\end{array}$} \\
\hline & & $\begin{array}{ll}\text { Country } & \text { IFRS }\end{array}$ & $\begin{array}{l}\text { Non- } \\
\text { IFRS }\end{array}$ & \\
\hline & & $\begin{array}{ll}\text { Developed } & 32 \\
\text { Developin } & 6 \\
\text { g } & \\
2001-2011 ; \\
\text { Panel data Regression }\end{array}$ & $\begin{array}{l}0 \\
13\end{array}$ & \\
\hline \multirow{3}{*}{$\begin{array}{l}\text { Hansen, } \\
\text { Miletkov } \\
\text { and } \\
\text { Wintoki } \\
(\mathbf{2 0 1 3 )}\end{array}$} & \multirow{3}{*}{$\begin{array}{l}\text { Look at when does } \\
\text { the IFRS adoption } \\
\text { increases foreign } \\
\text { ownership. }\end{array}$} & $\begin{array}{l}54552 \text { firm-year } \\
\text { observations from } 72 \\
\text { countries }\end{array}$ & & \multirow{3}{*}{$\begin{array}{l}\text { Foreign ownership is higher } \\
\text { for IFRS firms with strong } \\
\text { reporting incentives and } \\
\text { more transparent financial } \\
\text { disclosures. }\end{array}$} \\
\hline & & $\begin{array}{ll}\text { Country } & \text { IFRS }\end{array}$ & $\begin{array}{l}\text { Non- } \\
\text { IFRS }\end{array}$ & \\
\hline & & $\begin{array}{ll}\text { Developed } & 34 \\
\text { Developin } & 9 \\
\text { g } & \\
\text { 2001-2011; Panel dat } \\
\text { regressions }\end{array}$ & $\begin{array}{l}8 \\
21\end{array}$ & \\
\hline \multirow{3}{*}{$\begin{array}{l}\text { Hong, } \\
\text { Hung and } \\
\text { Lobo } \\
(\mathbf{2 0 1 4})\end{array}$} & \multirow{3}{*}{$\begin{array}{l}\text { Look at the effects of } \\
\text { IFRS adoption on the } \\
\text { relative change in } \\
\text { foreign capital or } \\
\text { investment flows } \\
\text { through initial public } \\
\text { offering (IPO). }\end{array}$} & $\begin{array}{l}3651 \text { IPOs from } 29 \\
\text { countries. }\end{array}$ & & \multirow{3}{*}{$\begin{array}{l}\text { IFRS adoption has a } \\
\text { substantial positive effect on } \\
\text { foreign capital flows. This } \\
\text { finding is more evident to } \\
\text { firms from countries that } \\
\text { ensure strong implementation } \\
\text { credibility. }\end{array}$} \\
\hline & & $\begin{array}{ll}\text { Country } & \text { IFRS }\end{array}$ & $\begin{array}{l}\text { Non- } \\
\text { IFRS }\end{array}$ & \\
\hline & & $\begin{array}{ll}\text { Developed } & 18 \\
\text { Developin } & 2 \\
\text { g } & \\
\end{array}$ & $\begin{array}{l}5 \\
4\end{array}$ & \\
\hline $\begin{array}{l}\text { Hsu and } \\
\text { Lai }(2013)\end{array}$ & $\begin{array}{l}\text { Look at whether } \\
\text { foreign investors are } \\
\text { differentially } \\
\text { attracted to firms that } \\
\text { mandatorily converge } \\
\text { into IFRS. }\end{array}$ & \multicolumn{2}{|c|}{$\begin{array}{l}10209 \text { firm-year } \\
\text { observations are representing } \\
1505 \text { firms in Taiwan } \\
\text { (Developed Country); } \\
\text { 2005-2012; } \\
\text { Multivariate regression } \\
\text { analysis }\end{array}$} & $\begin{array}{l}\text { Foreign mutual fund } \\
\text { ownership is greater among } \\
\text { companies affected by IFRS- } \\
\text { based standards than } \\
\text { companies using domestic } \\
\text { reporting standards. }\end{array}$ \\
\hline $\begin{array}{l}\text { Hsu, Jung } \\
\text { and } \\
\text { Pourjalali } \\
(\mathbf{2 0 1 5})\end{array}$ & $\begin{array}{l}\text { Investigate the impact } \\
\text { of (IAS) - } 27 \\
\text { adoptions on foreign } \\
\text { shareholdings. }\end{array}$ & \multicolumn{2}{|l|}{$\begin{array}{l}420 \text { firms from Taiwan } \\
\text { (Developed Country); } \\
\text { 2001-2008; } \\
\text { Panel data analysis }\end{array}$} & $\begin{array}{l}\text { Adoption of IAS- } 27 \\
\text { increases foreign } \\
\text { shareholdings of Taiwanese } \\
\text { firms. }\end{array}$ \\
\hline
\end{tabular}




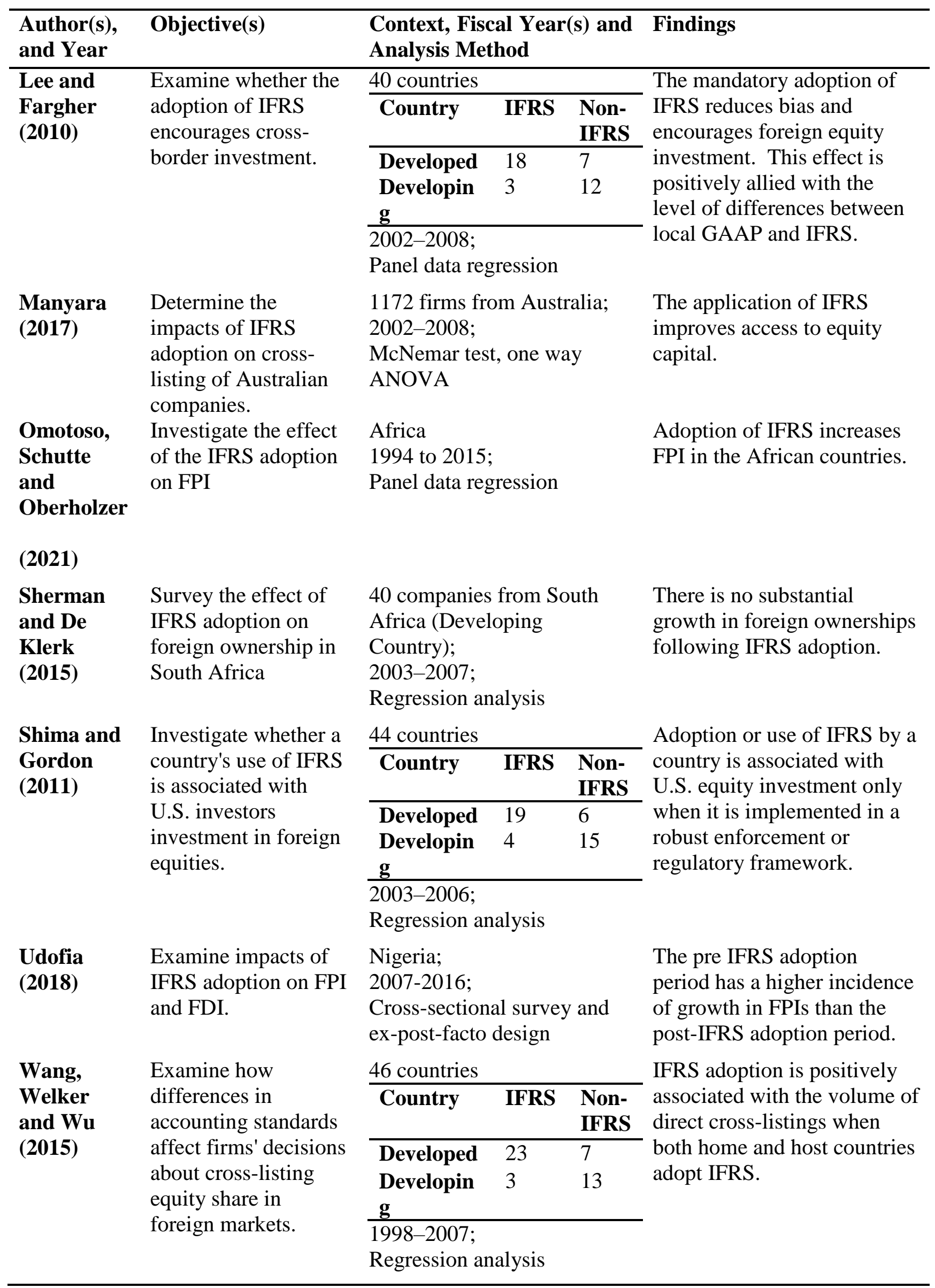




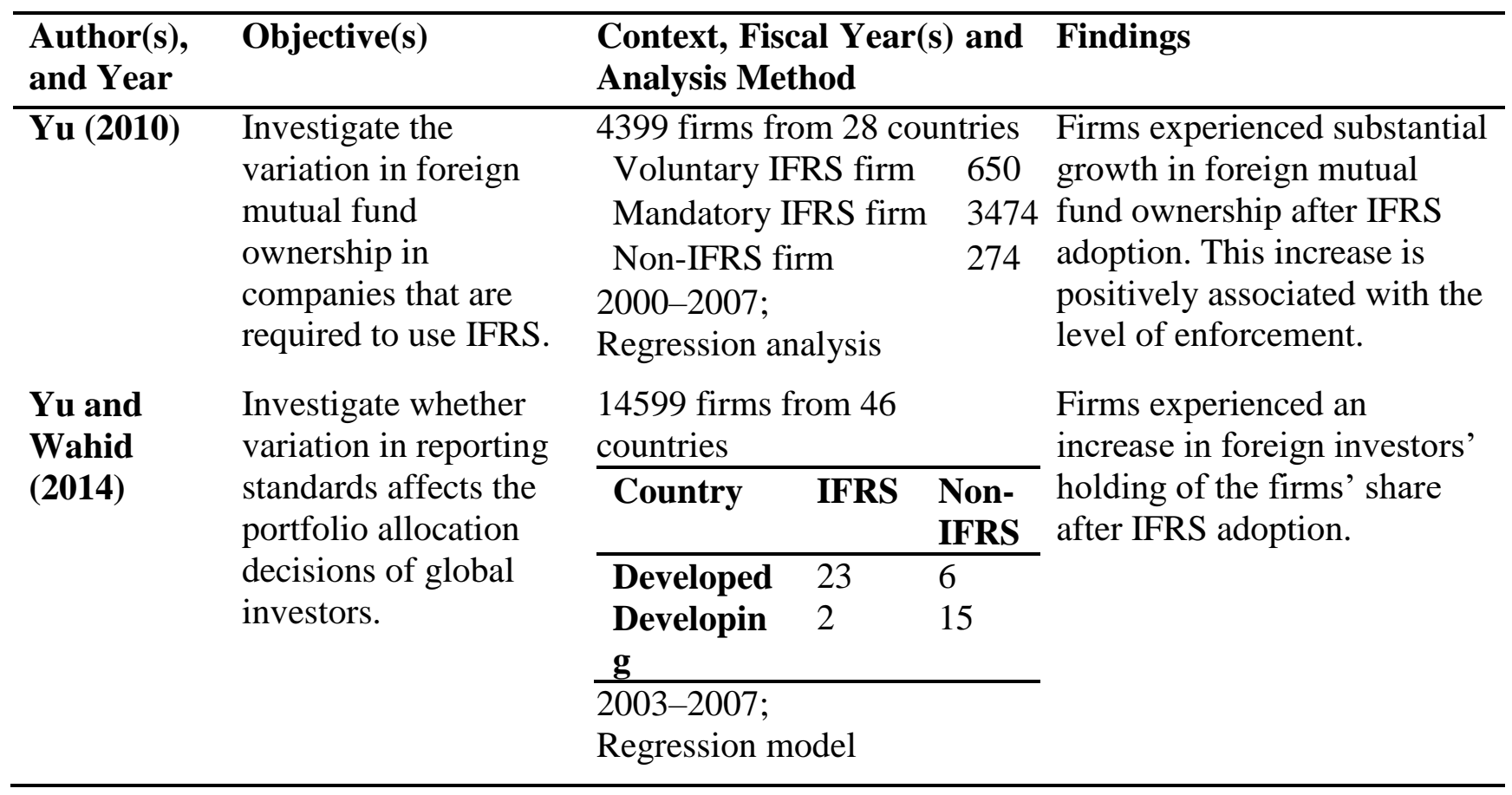

\section{IFRS ADOPTION, INVESTOR PROTECTION, AND FPI}

Investor protection is defined as the protection of investors such as stockholders, bondholders, and creditors by the legal framework of a country (Porta, Lopez, Shleifer, \& Vishny, 2000). It indicates efforts and actions taken by a country to monitor, defend, and enforce the rights of the investors (Jeanjean, 2012). In accounting standards, investor protection designates something to ensure that investors have enough information to make informed investment and voting decisions. It also specifies the action to prevent misleading disclosures and legal framework from protecting investors from dishonest investment brokers (Selling, 2011).

To what extent the investor's interest is protected from expropriation is a primary concern of foreign investors, particularly minority shareholders (Poshakwale \& Thapa 2011). Therefore, investor protection is a significant determinant of cross-border capital flows as well as portfolio diversification (Aggarwal et al., 2005; Leuz, Lins, \& Warnock 2010; Poshakwale \& Thapa, 2011; Florou \& Pope, 2012; Hansen et al., 2015). Recently, academics have started to investigate the relationship between investor protection and investors' portfolio holdings. A number of literature suggest that the extent of investor protection is positively associated with FPI (Giannetti \& Koskinen, 2010; Poshakwale \& Thapa, 2011; Giofré, 2014). The rationale of this argument is that investors are confident and prefer to invest in a market where investors' rights are strongly protected by the legal framework of a country (Poshakwale $\&$ Thapa, 2011). On the other hand, investors are reluctant or avoid investing in markets or countries that do not properly protect investors' rights (Giannetti \& Koskinen, 2010; Giofré, 2014). This is because foreign investors face information problems in countries with lower-level investor protection (Leuz et al., 2010).

A number of researchers investigate how the level of investor protection affects cross-border capital flows and foreign investor's assets allocation decisions (see Table 2 for details). Using a sample of 14 major investing countries for 2001-2006, Giofré (2013) reveals a significant cross effect of the level of investor protection rights on FPI. In the same vein, Aggarwal et al. (2005), Giannetti and Koskinen (2010) and Poshakwale and Thapa (2011) find that foreign institutional investors such as mutual funds choose to invest in developing/emerging countries or markets with the strong regulatory framework, investor protection, and high-quality accounting standards. On the other hand, Leuz et al. (2010) conclude that foreign investors are unwilling to invest in companies that reside in a jurisdiction with weak disclosure practice and poor protection of shareholder's rights. In addition, Porta, Lopez, 
Shleifer, \& Vishny (1997) show that the stock and debt market is significantly tiny in countries where investor rights are not strongly protected. They claim that the level of enforcement and quality of the legal framework significantly differs across the jurisdiction. Therefore, the difference in legal protection can justify why companies in some jurisdictions attract more capital than others (Poshakwale \& Thapa, 2011).

Prior research works (Ball, Kothari, \& Robin, 2000; Ball, Robin, \& Wu, 2003; Lang, Raedy, \& Wilson, 2006; Epstein, 2009) suggest that the benefits of uniform financial reporting standards can differ significantly across jurisdictions. In addition, Holthausen (2009) reveals that the legal and institutional framework, such as the extent of investor protection, substantially affects the outcomes of financial reporting standards. Prior research works that measure the impact of IFRS on FPI suggest that adoption of IFRS significantly increase the FPI, but the results are more pronounced in countries that ensure better investor protection (Yu, 2010; Shima \& Gordon, 2011; Amiram, 2012; Beneish et al., 2015; Hansen et al., 2015). For example, Yu (2010) finds that adopting IFRS helps attract greater foreign capital. This finding is more evident in a country that ensures the protection of shareholder's rights. Similarly, Beneish et al. (2015) assert that foreign portfolio investment is positively associated to the level of creditors' rights and governance quality in a country. In the same vein, Amiram (2012) finds that countries that provide better protection to shareholders' or investors' rights experienced substantial foreign equity investment growth. Likewise, Hansen et al.(2015) find that firms that reside in a country that provides high-level investor protection can attract more foreign investors or foreign investment by increasing the transparency of financial information. These findings suggest that adopting IFRS itself may not be enough to attract FPI if the investor's rights are not well protected.

Table 2. Summary of studies on the association between IFRS adoption, investor protection, and FPI

\begin{tabular}{|c|c|c|c|c|c|}
\hline $\begin{array}{l}\text { Author(s), } \\
\text { and Year }\end{array}$ & Objective(s) & \multicolumn{3}{|c|}{$\begin{array}{l}\text { Context, Fiscal Year(s), and } \\
\text { Analysis Methods }\end{array}$} & Findings \\
\hline $\begin{array}{l}\text { Aggarwal, } \\
\text { Klapper } \\
\text { and } \\
\text { Wysocki } \\
\text { (2005) }\end{array}$ & $\begin{array}{l}\text { Investigate the } \\
\text { asset allocation } \\
\text { decisions of U.S. } \\
\text { investors in an } \\
\text { emerging stock } \\
\text { market. }\end{array}$ & $\begin{array}{l}30 \text { countries } \\
\text { Developed } \\
\text { Developing } \\
\text { 2001-2002; } \\
\text { Regression an }\end{array}$ & $\begin{array}{l}0 \\
30\end{array}$ & & $\begin{array}{l}\text { Countries with strong } \\
\text { investor protection and } \\
\text { regulatory environment } \\
\text { experienced greater U.S. } \\
\text { mutual fund holdings. }\end{array}$ \\
\hline \multirow[t]{2}{*}{$\begin{array}{l}\text { Amiram } \\
(2012)\end{array}$} & \multirow{2}{*}{$\begin{array}{l}\text { Investigate the } \\
\text { impacts of } \\
\text { mandatory } \\
\text { adoption of IFRS } \\
\text { on FPI. }\end{array}$} & $\frac{104 \text { countries }}{\text { Country }}$ & IFRS & $\begin{array}{l}\text { Non- } \\
\text { IFRS } \\
\end{array}$ & \multirow{2}{*}{$\begin{array}{l}\text { The positive effect of IFRS } \\
\text { adoption on FPI is more } \\
\text { evident in countries where } \\
\text { investors' rights are well- } \\
\text { protected. }\end{array}$} \\
\hline & & $\begin{array}{l}\text { Developed } \\
\text { Developing } \\
\end{array}$ & $\begin{array}{l}37 \\
16 \\
\end{array}$ & $\begin{array}{l}6 \\
22 \\
\end{array}$ & \\
\hline \multirow{2}{*}{$\begin{array}{l}\text { Beneish, } \\
\text { Miller and } \\
\text { Yohn } \\
(\mathbf{2 0 1 5})\end{array}$} & \multirow{2}{*}{$\begin{array}{l}\text { Investigate the } \\
\text { relationship } \\
\text { between mandatory } \\
\text { IFRS adoption and } \\
\text { FPI. }\end{array}$} & $\frac{47 \text { countries }}{\text { Country }}$ & IFRS & $\begin{array}{l}\text { Non- } \\
\text { IFRS }\end{array}$ & \multirow{2}{*}{$\begin{array}{l}\text { The growth in foreign } \\
\text { equity ownership following } \\
\text { IFRS adoption is positively } \\
\text { associated with the } \\
\text { country's creditor rights. }\end{array}$} \\
\hline & & $\begin{array}{l}\text { Developed } \\
\text { Developing } \\
\end{array}$ & $\begin{array}{l}21 \\
2 \\
\end{array}$ & $\begin{array}{l}8 \\
14 \\
\end{array}$ & \\
\hline $\begin{array}{l}\text { Giannetti } \\
\text { and } \\
\text { Koskinen } \\
(2010)\end{array}$ & $\begin{array}{l}\text { Examine the } \\
\text { impacts of investor } \\
\text { protection on } \\
\text { investors' assets } \\
\text { allocation } \\
\text { decisions. }\end{array}$ & $\begin{array}{l}39 \text { countries } \\
\text { Developed } \\
\text { Developing } \\
2002 ; \\
\text { Regression an }\end{array}$ & $\begin{array}{r}27 \\
12 \\
\text { lysis }\end{array}$ & & $\begin{array}{l}\text { Foreign investors from } \\
\text { countries where investors' } \\
\text { rights are not well } \\
\text { protected prefer to invest } \\
\text { more in foreign equities. }\end{array}$ \\
\hline
\end{tabular}




\begin{tabular}{|c|c|c|c|c|c|}
\hline $\begin{array}{l}\text { Author(s), } \\
\text { and Year }\end{array}$ & Objective(s) & \multicolumn{3}{|c|}{$\begin{array}{l}\text { Context, Fiscal Year(s), and } \\
\text { Analysis Methods }\end{array}$} & Findings \\
\hline $\begin{array}{l}\text { Giofré } \\
(\mathbf{2 0 1 4})\end{array}$ & $\begin{array}{l}\text { Investigate the } \\
\text { effect of local } \\
\text { investor protection } \\
\text { on FPI. }\end{array}$ & \multicolumn{3}{|c|}{$\begin{array}{l}34 \text { countries } \\
\text { Developed } \quad 33 \\
\text { Developing } \quad 1 \\
\text { 2001-2006; } \\
\text { Multivariate analysis }\end{array}$} & $\begin{array}{l}\text { Strong investment } \\
\text { protection at home attracts } \\
\text { inward portfolio } \\
\text { investment. }\end{array}$ \\
\hline $\begin{array}{l}\text { Giofré } \\
(\mathbf{2 0 1 3})\end{array}$ & $\begin{array}{l}\text { Investigate the } \\
\text { effect of investor } \\
\text { protection on } \\
\text { international capital } \\
\text { flows. }\end{array}$ & $\begin{array}{l}14 \text { countries } \\
\text { Developed } \\
\text { Developing } \\
\text { 2001-2006; } \\
\text { Regression an }\end{array}$ & $\begin{array}{l}14 \\
0\end{array}$ & & $\begin{array}{l}\text { The legal framework for } \\
\text { investor protection has } \\
\text { substantial "cross", effects } \\
\text { on FPI. }\end{array}$ \\
\hline \multirow{3}{*}{$\begin{array}{l}\text { Hansen, } \\
\text { Miletkov } \\
\text { and } \\
\text { Wintoki } \\
(\mathbf{2 0 1 5})\end{array}$} & \multirow{3}{*}{$\begin{array}{l}\text { Look at the effect } \\
\text { of investor } \\
\text { protection on the } \\
\text { transparency of } \\
\text { financial reporting } \\
\text { and foreign } \\
\text { shareholdings. }\end{array}$} & \multicolumn{3}{|c|}{$\begin{array}{l}55239 \text { firm-year observations } \\
\text { from } 51 \text { countries }\end{array}$} & \multirow{3}{*}{$\begin{array}{l}\text { Firms experienced greater } \\
\text { foreign ownership } \\
\text { following IFRS adoption in } \\
\text { countries that ensure strong } \\
\text { investor protection. }\end{array}$} \\
\hline & & Country & IFRS & $\begin{array}{l}\text { Non- } \\
\text { IFRS }\end{array}$ & \\
\hline & & $\begin{array}{c}\text { Developed } \\
\text { Developing } \\
2001-2011\end{array}$ & $\begin{array}{l}32 \\
6 \\
\end{array}$ & $\begin{array}{l}0 \\
13 \\
\end{array}$ & \\
\hline $\begin{array}{l}\text { Leuz, Lins } \\
\text { and } \\
\text { Warnock } \\
(\mathbf{2 0 1 0})\end{array}$ & $\begin{array}{l}\text { Investigate the } \\
\text { relationship } \\
\text { between corporate } \\
\text { governance and } \\
\text { cross-border capital } \\
\text { flows. }\end{array}$ & $\begin{array}{l}4409 \text { firms fro } \\
\text { Developed } \\
\text { Developing } \\
\text { 1997; } \\
\text { Regression an }\end{array}$ & $\begin{array}{l}29 \text { co } \\
21 \\
8 \\
\text { lysis }\end{array}$ & ntries & $\begin{array}{l}\text { Foreign investors invest } \\
\text { less in firms that reside in } \\
\text { countries where investor's } \\
\text { rights are not well- } \\
\text { protected. }\end{array}$ \\
\hline $\begin{array}{l}\text { Poshakwal } \\
\text { e and } \\
\text { Thapa } \\
\text { (2011) }\end{array}$ & $\begin{array}{l}\text { Examine the effects } \\
\text { of investor } \\
\text { protection on cross- } \\
\text { border portfolio } \\
\text { investment. }\end{array}$ & \multicolumn{3}{|c|}{$\begin{array}{l}36 \text { countries } \\
\text { Developed } 24 \\
\text { Developing } \quad 12 \\
\text { 2001-2006; } \\
\text { Regression analysis }\end{array}$} & $\begin{array}{l}\text { The quality of legal } \\
\text { protection offered to } \\
\text { foreign investors has } \\
\text { positive impacts on foreign } \\
\text { portfolio investment. }\end{array}$ \\
\hline \multirow[t]{2}{*}{$\begin{array}{l}\text { Shima and } \\
\text { Gordon } \\
\text { (2011) }\end{array}$} & $\begin{array}{l}\text { Examine whether } \\
\text { the wider } \\
\text { regulatory }\end{array}$ & $\frac{44 \text { countries }}{\text { Country }}$ & IFRS & $\begin{array}{l}\text { Non- } \\
\text { IFRS }\end{array}$ & \multirow{2}{*}{$\begin{array}{l}\text { IFRS adopting countries } \\
\text { can attract foreign capital } \\
\text { only when IFRS is } \\
\text { implemented in a robust } \\
\text { regulatory framework such } \\
\text { as strong investor } \\
\text { protection. }\end{array}$} \\
\hline & $\begin{array}{l}\text { environment is } \\
\text { associated with } \\
\text { U.S. investor's } \\
\text { holdings of foreign } \\
\text { equities. }\end{array}$ & \multicolumn{3}{|l|}{$2003-2006$} & \\
\hline $\begin{array}{l}\text { Wu, Li and } \\
\text { Selover } \\
(2012)\end{array}$ & $\begin{array}{l}\text { Look at the impact } \\
\text { of governance } \\
\text { quality on cross- } \\
\text { border investment } \\
\text { and the foreign } \\
\text { investment it } \\
\text { attracts. }\end{array}$ & \multicolumn{3}{|c|}{$\begin{array}{l}45 \text { countries } \\
\text { Developed } 20 \\
\text { Developing } 25 \\
\text { 2005-2008; } \\
\text { Regression analysis }\end{array}$} & $\begin{array}{l}\text { The level of property } \\
\text { protection with diverse } \\
\text { governance models has a } \\
\text { substantial impact on both } \\
\text { FPI and FDI. }\end{array}$ \\
\hline
\end{tabular}




\section{SUGGESTION FOR FUTURE RESEARCH}

This section suggests three research avenues for future researchers to enhance their understanding of the topic reviewed in this study.

Although a large number of literature endeavors to measure the economic consequence of IFRS, most of these studies have taken place in developed countries (Lin, 2012; Singleton-Green, 2015). On the other hand, limited research investigates the economic effects of adopting IFRS in developing countries (Lin, 2012; Herbert \& Tsegba, 2013; Efobi Uchenna, 2016; Samaha \& Khlif, 2016). It is argued that developing countries suffer from weak institutional infrastructure that may cause lower quality compliance with accounting standards (Stecher \& Suijs, 2012). Consequently, the expected economic benefits of IFRS adoption is uncertain under weak compliance with the IFRS (Stecher \& Suijs, 2012). This implies IFRS adoption in developing countries might not result in the appropriate accounting system (Tyrrall, Woodward, \& Rakhimbekova, 2007). Therefore, although the prior study shows the overall positive effect of IFRS adoption, the outcome may not directly apply or less likely to be generalizable to developing countries (Lin, 2012; Mohammadrezaei et al., 2015). While there is no sufficient evidence to confirm that developing countries benefit from adopting the standards (Lin, 2012; Stecher \& Suijs, 2012; Herbert \& Tsegba, 2013; Efobi Uchenna, 2016; Samaha \& Khlif, 2016), it is worthwhile to conduct further research on the impacts of IFRS adoption on FPI in the context of developing countries (Lin, 2012).

Since every country is different in terms of institutions, economics, and politics, many researchers suggest conducting research focusing more on specific settings such as an individual country (Daske, 2012; Brüggemann et al., 2013; De George et al., 2016; Efobi Uchenna, 2016; Houqe et al., 2016). This is because more controlled experiments are possible in a single country (or settings), which facilitates more precise identification. Also, proprietary data is more likely to become available in a single country that is necessary to establish direct causes and effects in empirical studies (Daske, 2012). Finally, country-specific or single-country research should increase the validity of the research outcome by enabling researchers to understand and control concurrent non-IFRS effects (Brüggemann et al., 2013; Singleton-Green, 2015; Efobi Uchenna, 2016; Houqe et al., 2016). In addition, it is observed that prior IFRS adoption literature are mainly concentrated on cross-country research (Daske, 2012). Therefore, future research should focus more on a single country setting to reveal the precise effect of IFRS adoption on FPI.

There is a substantial variation in accounting practice between countries even though they use the same accounting standards (Pricope, 2016). This is because the process of implementing accounting standards is not the same for all countries (Schipper, 2005; Kvaal and Nobes, 2012). In addition, differences in institutional settings also cause variation in interpretation and use of IFRS between countries (Schipper, 2005; Whittington, 2005; Pope \& McLeay, 2011). These findings suggest that the implementation and level of compliance with IFRS standards vary between countries due to their institutional settings. Rationally, the expected effect of IFRS adoption will differ among jurisdictions. It is also evidenced that the benefits of IFRS are tied to some country-level factors (Tarca, 2012). Since the investors, assets allocation decision is affected by the level of investor protection, and investors prefer to invest in a country where investors' legal rights are strongly protected by law, future research should consider the effect of investor protection in relation to IFRS adoption and FPI.

\section{CONCLUSION}

Based on the existing empirical literature, this study investigates the effect of IFRS adoption on FPI regarding investor protection, focusing on developed vs. developing countries. It was revealed that the impacts of IFRS on FPI vary significantly between developed and developing countries. Although it is evidenced that FPI increased following IFRS adoption, there is limited evidence that IFRS adoption improved FPI in developing countries. The empirical research findings concerning the impact of IFRS adoption on FPI should be interpreted carefully with country-specific factors such as regulatory environment and investor protection. Empirical evidence regarding the effects of IFRS adoption on FPI is inadequate to make a conclusion regarding impacts of IFRS on FPI on developing country perspective. 
Further research is required on this topic considering country-specific factors, particularly developing country perspectives

\section{REFERENCES}

Abid, F., Leung, P. L., Mroua, M., \& Wong, W. K. (2014). International diversification versus domestic diversification: Mean-variance portfolio optimization and stochastic dominance approaches. Journal of Risk and Financial Management, 7(2), 45-66. https://doi.org/10.3390/jrfm7020045

Ackert, L. F., Church, B. K., Tompkins, J., \& Zhang, P. (2005). What's in a name? An experimental examination of investment behaviour. Review of Finance, 9(2), 281-304. https://doi.org/10.100 7/s10679 -005-7594-2

Aggarwal, R., Klapper, L., \& Wysocki, P. D. (2005). Portfolio preferences of foreign institutional investors. Journal of Banking and Finance, 29(12), 2919-2946. https://doi.org/10.1016/j.jbankfi n.2004.09.008

Ahearne, A. G., Griever, W. L., \& Warnock, F. E. (2004). Information costs and home bias: An analysis of U.S. holdings of foreign equities. Journal of International Economics, 62(2), 313-336. https://doi.org/10.1016/S0022-1996(03)00015-1

Ahmed, K., Chalmers, K., \& Khlif, H. (2013). A meta-analysis of IFRS adoption effects. The International Journal of Accounting, 48(2), 173-217. https://doi.org/10.1016/j.intacc.2013.04.00 2

AICPA (2021). International financial reporting standards. Retrieved from https://www.ifrs.com/ updates/aicpa/ifrs_faq.html\#q1

Akisik, O., \& Pfeiffer, R. (2009). Globalization, U.S. foreign investments and accounting standards. Review of Accounting and Finance, 8(1), 5-37. https://doi.org/10.1108/14757700910934210

Amiram, D. (2012). Financial information globalization and foreign investment decisions. Journal of International Accounting Research, 11(2), 57-81. https://doi.org/10.2308/jiar-50282

Armstrong, C. S., Barth, M. E., Jagolinzer, A. D., \& Riedl, E. J. (2010). Market reaction to the adoption of IFRS in Europe. The Accounting Review, 85(1), 31-61. https://doi.org/10.2308/accr.2010.85.1 .31

Ashbaugh, H., \& Pincus, M. (2001). Domestic accounting standards, international accounting standards, and the predictability of earnings. Journal of Accounting Research, 39(3), 417-434. https://doi.org/10.1111/1475-679X.00020

Asness, C. S., Israelov, R., \& Liew, J. M. (2011). International diversification works (eventually). Financial Analysts Journal, 67(3), 24-38. https://doi.org/10.2469/faj.v67.n3.1

Babío, M. R., \& Muiño, M. F. (2005). Corporate characteristics, governance rules and the extent of voluntary disclosure in Spain. Advances in Accounting, Incorporating Advances in International Accounting, 21, 299-331. https://doi.org/10.1016/S0882-6110(05)21013-1

Ball, R., Kothari, S. P., \& Robin, A. (2000). The effect of international institutional factors on properties of accounting earnings. Journal of Accounting and Economics, 29(1), 1-51. https://do i.org/10.1016/S0165-4101(00)00012-4 
Ball, R., Robin, A., \& Wu, J. S. (2003). Incentives versus standards: Properties of accounting income in four East Asian countries. Journal of Accounting and Economics, 36(1), 235-270. https://doi.org /10.1016/j.jacceco.2003.10.003

Barth, M. E., Landsman, W. R., \& Lang, M. H., (2008). International accounting standards and accounting quality. Journal of Accounting Research, 46(3), 467-498. https://doi.org/10.1111 /j.1475-679X.2008.00287.x

Bartov, E., Goldberg, S. R., \& Kim, M. (2005). Comparative value relevance among German, U.S. and international accounting standards: A German stock market perspective. Journal of Accounting, Auditing \& Finance, 20(2), 95-119. https://doi.org/10.1177\%2F0148558X0502000201

Beneish, M. D., \& Yohn, T. L. (2008). Information friction and investor home bias: A perspective on the effect of global IFRS adoption on the extent of equity home bias. Journal of Accounting and Public Policy, 27(6), 433-443. https://doi.org/10.1016/j.jaccpubpol.2008.09.001

Beneish, M. D., Miller, B. P., \& Yohn, T. L. (2015). Macroeconomic evidence on the impact of mandatory IFRS adoption on equity and debt markets. Journal of Accounting and Public Policy, 34(1), 1-27. https://doi.org/10.1016/j.jaccpubpol.2014.10.002

Bova, F., \& Pereira, R. (2012). The determinants and consequences of heterogeneous IFRS compliance levels following mandatory IFRS adoption: Evidence from a developing country. Journal of International Accounting Research, 11(1), 83-111. https://doi.org/10.2308/jiar-10211

Bradshaw, M. T., Bushee, B. J.,\& Miller, G. S.(2004). Accounting choice, home bias, and U.S. investment in non-U.S. firms. Journal of Accounting Research, 42(5), 795-841. https://doi.org /10.1111/j.1475-679X.2004.00157.x

Brüggemann, U. (2011). The impact of mandatory IFRS adoption on cross-border equity investments of individual investors, In Essays on the economic consequences of mandatory IFRS reporting around the world, (pp. 45-82). Heidelberg: Gabler.

Brüggemann, U., Hitz, J-M., \& Sellhorn, T. (2013). Intended and unintended consequences of mandatory IFRS adoption: A review of extant evidence and suggestions for future research. European Accounting Review, 22(1), 1-37. https://doi.org/10.1080/09638180.2012.718487

Butler, K. C. (2016). Chapter 19: International portfolio diversification. In Multinational finance (pp. 457-484). New York, John Wiley \& Sons.

Caprio, G. (2012). Handbook of safeguarding global financial stability: Political, social, cultural, and economic theories and models, London, England: Elsevier.

Chen, L., Ng, J., \& Tsang, A. (2015). The effect of mandatory IFRS adoption on international crosslistings. The Accounting Review, 90(4), 1395-1435. https://doi.org/10.2308/accr-50982

Chipalkatti, N., Le, Q. V., \& Rishi, M. (2007). Portfolio flows to emerging capital markets: Do corporate transparency and public governance matter?. Business and Society Review, 112(2), 227-249. https://doi.org/10.1111/j.1467-8594.2007.00295.x

Coeurdacier, N., \& Rey, H. (2013). Home bias in open economy financial macroeconomics. Journal of Economic Literature, 51(1), 63-115. https://doi.org/10.1257/jel.51.1.63 
Cooper, I., \& Kaplanis, E. (1994). Home bias in equity portfolios, inflation hedging, and international capital market equilibrium. The Review of Financial Studies, 7(1), 45-60. https://doi.org/10.10 93/rfs/7.1.45

Cooper, I., Sercu, P.,\& Vanpée, R.(2013). The equity home bias puzzle: A survey.Foundations and Trends® in Finance, 7(4), 289-416.

Coval, J. D., \& Moskowitz, T. J. (1999). Home bias at home: Local equity preference in domestic portfolios. The Journal of Finance, 54(6), 2045-2073. https://doi.org/10.1111/0022-1082.00181

Covring, V. M., Defond, M. L., \& Hung, M. (2007). Home bias, foreign mutual fund holdings, and the voluntary adoption of international accounting standards. Journal of Accounting Research, 45(1), 41-70. https://doi.org/10.1111/j.1475-679X.2007.00226.x

Daske, H. (2012). Economic effects of transparency in international equity markets: A review and suggestions for future research. The Accounting Review, 87(5), 1821-1823.

De George, E. T., Li, X., \& Shivakumar, L. (2016). A review of the IFRS adoption literature. Review of Accounting Studies, 21(3), 898-1004. https://doi.org/10.1007/s11142-016-9363-1

De Santis, R. A. (2010). The geography of international portfolio flows, international CAPM, and the role of monetary policy frameworks. International Journal of Central Banking, 6(2), 147-197.

DeFond, M., Hu, X., Hung, M., \& Li, S. (2011). The impact of mandatory IFRS adoption on foreign mutual fund ownership: The role of comparability. Journal of Accounting and Economics, 51(3), 240-258. https://doi.org/10.1016/j.jacceco.2011.02.001

DeFond, M. L., Gao, X., Li, O. Z., \& Xia, L. (2014). Did China's adoption of IFRS attract more foreign institutional investment?. SSRN. Retrieved from https://ssrn.com/abstract=2426484

DeFond, M. L., Hu, X., Hung, M. Y., \& Li, S. (2012). Has the widespread adoption of IFRS reduced U.S. firms' attractiveness to foreign investors?. Journal of International Accounting Research, 11(2), 27-55. https://doi.org/10.2308/jiar-50205

Efobi, U., Sailesh, T., \& Francis I. (2016). Economics and political implications of international financial reporting standards, Hershey, USA: IGI Global.

Epstein, B. J. (2009). The economic effects of IFRS adoption. The CPA Journal, 79(3), 26-31.

Faruqee, H., Li, S., \& Yan, I.K. (2004). The determinants of international portfolio holdings and home bias. IMF Working Paper No. 04/34, Retrieved from https://ssrn.com/abstract=878857

Florou, A. \& Pope, P. F. (2012). Mandatory IFRS adoption and institutional investment decisions. The Accounting Review, 87(6), 1993-2025. https://doi.org/10.2308/accr-50225

French, K. R. \& Poterba, J. M. (1991). Investor diversification and international equity markets. The American Economic Review, 81(2), 222-226.

Garrouch, H. (2016). Reaction of foreign institutional investors to mandatory IFRS adoption: French evidence. International Journal of Economics and Finance, 8(11), 30-47. http://dx.doi.org/10. 5539/ijef.v8n11p30 
Gehrig, T. (1993). An information based explanation of the domestic bias in international equity investment. Scandinavian Journal of Economics, 95(1), 97-109. https://doi.org/10.2307/3440 137

Giannetti, M., \& Koskinen, Y. (2010). Investor protection, equity returns, and financial globalization. Journal of Financial and Quantitative Analysis, 45(1), 135-168. https://doi.org/10.1017/S002 2109009990524

Giofré, M. (2013). Investor protection rights and foreign investment. Journal of Comparative Economics, 41(2), 506-526. https://doi.org/10.1016/j.jce.2012.07.002

Giofré, M. (2014). Domestic investor protection and foreign portfolio investment. Journal of Banking \& Finance, 46, 355-371. https://doi.org/10.1016/j.jbankfin.2014.05.027

Gokkent, G. M. (1997). Theory of foreign portfolio investment (Doctoral thesis, Florida International University, Ann Arbor). Retrieved from https://www.proquest.com/openview/0942c002e07 0271c72a0c864cbc6fd5b/1?pq-origsite $=$ gscholar \&cbl=18750\&diss $=y$

Grubel, H. G. (1968). Internationally diversified portfolios: Welfare gains and capital flows. The American Economic Review, 58(5),1299-1314.

Hamberg, M., Mavruk, T., \& Sjögren, S. (2013). Investment allocation decisions, home bias and the mandatory IFRS adoption. Journal of International Money and Finance, 36, 107-130. https:// doi.org/10.1016/j.jimonfin.2013.04.001

Han, B., Yi, J., Park, I., \& Seo, Y. (2016). IFRS adoption and capital globalization in Korea, Korea Accounting Standards Board Research Report. Retrieved from https://www.uad.sk/ download/onlibdu/Research_Report_No.38_IFRS_adoption_and_capital_globalization_in_Kor ea.pdf

Hansen, B., Miletkov, M., \& Wintoki, M. B. (2013). When does the adoption and use of IFRS increase foreign investment. CiteSeerX. Retrieved from https://citeseerx.ist.psu.edu/viewdoc/download? doi=10.1.1.431.9083\&rep=rep1\&type $=$ pdf

Hansen, B., Miletkov, M. K., \& Wintoki, M. B. (2015). Investor protection and the role of firm-level financial transparency in attracting foreign investment. Financial Review, 50(3), 393-434. https://doi.org/10.1111/fire.12072

Herbert, W. E., \& Tsegba, I. N. (2013). Economic consequences of international financial reporting standards (IFRS) adoption: Evidence from a developing country. European Journal of Business and Management, 5(28), 80-99.

Holthausen, R. W. (2009). Accounting standards, financial reporting outcomes, and enforcement. Journal of Accounting Research, 47(2), 447-458.

Hong, H. A., Hung, M., \& Lobo, G. J. (2014). The impact of mandatory IFRS adoption on IPOs in global capital markets. The Accounting Review, 89(4), 1365-1397. https://doi.org/10.2308/accr-50720

Houqe, M. N., Monem, R. M., \& Zijl, T. (2016). The economic consequences of IFRS adoption: Evidence from New Zealand. Journal of International Accounting, Auditing and Taxation, 27, 40-48. https://doi.org/10.1016/j.intaccaudtax.2016.10.001 
Houqe, N. (2018). A review of the current debate on the determinants and consequences of mandatory IFRS adoption. International Journal of Accounting \& Information Management, 26(3), 413442. https://doi.org/10.1108/IJAIM-03-2017-0034

Hsu, AW-h., Jung, B., \& Pourjalali, H. (2015). Does international accounting standard no. 27 improve investment efficiency?. Journal of Accounting, Auditing \& Finance, 30(4), 484-508. https://doi. org/10.1177\%2F0148558X15582087

Hsu, C. H., \& Lai, S. C. (2013). How does mandatory IFRS convergence impact on foreign investment? Evidence from Taiwan,. In 23rd International business research conference (pp. 1-27). Melbourne, Australia.

IASB. (2002). Annual report 2002, London, UK. Retrieved from https://www.ifrs.org

Jeanjean, T. (2012). The effect of IFRS adoption, investor protection and earnings quality: Some reflections. The International Journal of Accounting, 47(3), 356-362. https://doi.org/10.1016/j. intacc.2012.07.005

Karolyi, G. A., \& Stulz, R. M. (2003). Chapter 16: Are financial assets priced locally or globally? In Handbook of the Economics of Finance (pp. 975-1020). New York, NY: North Holland Publishers

Khlif, H., \& Achek, I. (2016). IFRS adoption and auditing: a review. Asian Review of Accounting. 24(3), 338-361. https://doi.org/10.1108/ARA-12-2014-0126

Khurana, I. K., \& Michas, P. N. (2011). Mandatory IFRS adoption and the U.S. home bias. Accounting Horizons, 25(4), 729-753. https://doi.org/10.2308/acch-50075

Kvaal, E., \& Nobes, C. (2012). IFRS policy changes and the continuation of national patterns of IFRS practice. European Accounting Review, 21(2), 343-371. https://doi.org/10.1080/09638180.2011 .611236

Lang, M., Smith Raedy, J., \& Wilson, W. (2006). Earnings management and cross listing: Are reconciled earnings comparable to U.S. earnings?. Journal of Accounting and Economics, 42(1), 255-283. https://doi.org/10.1016/j.jacceco.2006.04.005

Lee, G., \& Fargher, N. L. (2010). Did the adoption of IFRS encourage cross-border investment?. SSRN. Retrieved from https://ssrn.com/ abstract=1686571

Leuz, C. (2003). IAS versus U.S. GAAP: Information asymmetry-based evidence from Germany's new market. Journal of Accounting Research, 41(3), 445-472. https://doi.org/10.1111/1475679X.00112

Leuz, C., Lins, KV., \& Warnock, F. E. (2010). Do foreigners invest less in poorly governed firms?. Review of Financial Studies, 23(3), 3245-3285. https://doi.org/10.1093/rfs/hhn089

Levitt, A.(1998). The importance of high quality accounting standards. Accounting Horizons, 12(1), 7982.

Levy, H., \& Sarnat, M. (1970). International diversification of investment portfolios. The American Economic Review, 60(4), 668-675. 
Lewis, K. K. (1995). Chapter 37 Puzzles in international financial markets, In Handbook of International Economics ( pp. 1913-1971). Amsterdam: Elsevier

Lewis, K. K. (1999). Trying to explain home bias in equities and consumption. Journal of Economic Literature, 37(2), 571-608. https://doi.org/10.1257/jel.37.2.571

Lin, S. (2012). Discussion of the determinants and consequences of heterogeneous IFRS compliance levels following mandatory IFRS adoption: Evidence from a developing country. Journal of International Accounting Research, 11(1), 113-118. https://doi.org/10.2308/jiar-10226

Manyara, S. (2017). Impact of implementing uniform accounting standards on equity investments. International Journal of Social Science and Business, 2(4), 7-16.

Markowitz, H. (1952). Portfolio selection. The Journal of Finance, 7(1),77-91.

Markowitz, H. (1959). Portfolio selection: Efficient diversification of investments. New York: John Wiley and Sons,

Márquez-Ramos, L. (2011). European accounting harmonisation: Consequences of IFRS adoption on trade in goods and foreign direct investments. Emerging Markets Finance and Trade, 47(sup4), 42-57. https://doi.org/10.2753/REE1540-496X4705S403

Mohammadrezaei, F., Mohd-Saleh, N., \& Banimahd, B. (2015). The effects of mandatory IFRS adoption: A review of evidence based on accounting standard setting criteria. International Journal of Disclosure and Governance, 12(1), 29-77. https://doi.org/10.1057/jdg.2013.32

Nieuwerburgh, S. V., \&Veldkamp, L. (2009). Information immobility and the home bias puzzle. The Journal of Finance, 64(3), 1187-1215. https://doi.org/10.1111/j.1540-6261.2009.01462.x

Nnadi, M., \& Soobaroyen, T. (2015). International financial reporting standards and foreign direct investment: The case of Africa. Advances in Accounting, 31(2), 228-238. https://doi.org/10.1016 /j.adiac.2015.09.007

Omotoso, M.O., Schutte, D. P., \& Oberholzer, M. (2021). The effect of the adoption of International Financial Reporting Standards on foreign portfolio investment in Africa, South African Journal of Accounting Research. https://doi.org/10.1080/10291954.2021.1909940

Păşcan, I. D. (2015). Measuring the effects of IFRS adoption on accounting quality: A review. Procedia Economics and Finance, 32, 580-587. https://doi.org/10.1016/S2212-5671(15)01435-5

Pope, P. F., \& McLeay, S. J. (2011). The European IFRS experiment: Objectives, research challenges and some early evidence. Accounting and Business Research, 41(3), 233-266. https://doi.org/10. $1080 / 00014788.2011 .575002$

Porta, R. L., Lopez-De-Silanes, F., Shleifer, A., \& Vishny, R. W. (1997). Legal determinants of external finance. The Journal of Finance, 52(3), 1131-1150. https://doi.org/10.1111/j.15406261.1997.tb02727.x

Porta, R., Lopez-de-Silanes, F., Shleifer, A., \& Vishny, R. (2000). Investor protection and corporate governance. Journal of Financial Economics, 58(1), 3-27. https://doi.org/10.1016/S0304405X (00)00065-9 
Poshakwale, S. S., \& Thapa, C. (2011). Investor protection and international equity portfolio investments. Global Finance Journal, 22(2), 116-129. https://doi.org/10.1016/j.gfj.2011.10.003

Pricope, C. F. (2016). The role of institutional pressures in developing countries-Implications for IFRS. Theoretical and Applied Economics, 23(2), 27-40.

Rueda-Sabater, E. (2000). Corporate governance: The bargaining power of developing countries to attract foreign investment. Corporate Governance: An International Review, 8(2), 117-124. https://doi.org/10.1111/1467-8683.00189

Samaha, K., \& Khlif, H. (2016). Adoption of and compliance with IFRS in developing countries: A synthesis of theories and directions for future research. Journal of Accounting in Emerging Economies, 6(1), 33-49. https://doi.org/10.1108/JAEE-02-2013-0011

Schipper, K. (2005). The introduction of international accounting standards in Europe: Implications for international convergence. European Accounting Review, 14(1), 101-126. https://doi.org/10. 1080/0963818042000338013

Selling, T. (2011). What should "investor protection" mean to accounting standards setters?. Retrieved from http://accountingonion.typepad.com/theaccountingonionwhat-should-investor-protectionmean-to-accounting-standards-etters.html

Sharpe, W. F. (1964). Capital asset prices: A theory of market equilibrium under conditions of risk. The Journal of Finance, 19(3), 425-442. https://doi.org/10.1111/j.1540-6261.1964.tb02865.x

Sherman, T., \& De Klerk, M. (2015). International financial reporting standards and foreign ownership in South African companies. Southern African Business Review, 19(1),72-88.

Shima, K. M., \& Gordon, E. A. (2011). IFRS and the regulatory environment: The case of U.S. investor allocation choice. Journal of Accounting and Public Policy, 30(5), 481-500. https://doi.org/10 .1016/j.jaccpubpol.2011.07.001

Shovon, M. K. H. (2019). Impacts of mandatory international financial reporting standards adoption on foreign shareholdings of public listed companies in Malaysia (Masters thesis). Retrieved from https://researchbank.swinburne.edu.au/items/ea118d78-7730-4e0e-be22-3a6bfdf75e18/1/

Singleton-Green, B. (2015). The effects of mandatory IFRS adoption in the E.U.: A review of empirical research. Information for Better Markets, 1-149.

Soderstrom, N. S., \& Sun, K. J. (2007). IFRS adoption and accounting quality: a review. European Accounting Review, 16(4), 675-702. https://doi.org/10.1080/09638180701706732

Solnik, B. H. (1974). Why not diversify internationally rather than domestically?. Financial Analysts Journal, 30(4), 48-54. https://doi.org/10.2469/faj.v30.n4.48

Solnik, B. H. (1995). Why not diversify internationally rather than domestically?. Financial Analysts Journal, 51(1), 89-94. https://doi.org/10.2469/faj.v51.n1.1864

Stecher, J., \& Suijs, J. (2012). Hail, procrustes! Harmonised accounting standards as a procrustean bed. Journal of Accounting and Public Policy, 31(4), 341-355. https://doi.org/10.1016/j.jaccpubpol .2012 .05 .003 
Tarca, A. (2004). International convergence of accounting practices: Choosing between IAS and U.S. GAAP. Journal of International Financial Management \& Accounting, 15(1), 60-91. https://doi.org/10.1111/j.1467-646X.2004.00102.x

Tarca, A. (2012). The case for global accounting standards: Arguments and evidence. SSRN. Retrieved from http://ssrn.com/abstract=2204889

Tesar, L. L., \& Werner, I. M. (1995). Home bias and high turnover. Journal of International Money and Finance, 14(4), 467-492. https://doi.org/10.1016/0261-5606(95)00023-8

Tyrrall, D., Woodward, D., \& Rakhimbekova, A. (2007), The relevance of international financial reporting standards to a developing country: Evidence from Kazakhstan. The International Journal of Accounting, 42(1), 82-110. https://doi.org/10.1016/j.intacc.2006.12.004

Udofia, I. E. (2018). IFRS adoption and cross border investment in Nigeria. Accounting and Management Information Systems, 17(4), 605-625.

Wang, S., Welker, M., \& Wu, S.S. (2015). The role of accounting standards in firms' cross-listing decisions. Retrieved from http://repository.ust.hk/ir/bitstream/1783.1-78429/1/AccountingStand ardsanCrosslisting20150220.pdf

White, J. W. (2008). IFRS and U.S. companies: A look ahead. Retrieved from https://www.sec.gov /news/speech/2008/spch060508jww.htm

Whittington, G. (2005). The adoption of international accounting standards in the European Union. European Accounting Review, 14(1), 127-153. https://doi.org/10.1080/0963818042000338022

Yan, I. K. (2004). The determinants of international portfolio holdings and home bias, Washington: IMF.

Yu, G. (2010). Accounting standards and international portfolio holdings: Analysis of cross-border holdings following mandatory adoption of IFRS. (Dctoral thesis, University of Michigan, Ann Arbor). Retrieved from https://deepblue.lib.umich.edu/handle/2027.42/77800

Yu, G., \& Wahid, A. S. (2014). Accounting standards and international portfolio holdings. Accounting Review, 89(5), 1895-1930. https://doi.org/10.2308/accr-50801

\section{Copyrights}

Copyright for this article is retained by the author(s), with first publication rights granted to the journal. This is an open-access article distributed under the terms and conditions of the Creative Commons Attribution license (https://creativecommons.org/licenses/by/4.0). 